\title{
Sovereign Debt Crisis in Europe: A Different Crisis with a “Less Than Different” Impact on Bangladesh?
}

\author{
Molla Mursaleen Shiraj, Afrin Islam \\ Student of MBA, Institute of Business Administration, University of Dhaka, Dhaka, Bangladesh \\ Business Consultant, Katalyst, Dhaka, Bangladesh \\ E-mail:mursaleenshiraj@gmail.com,afrin.islam@swisscontact-bd.org \\ Received June 8, 2011; revised July 10, 2011; accepted July 19, 2011
}

\begin{abstract}
Global economy is going through another round of rough patches. Right after an economic turmoil that originated in the USA, the global economy is experiencing a debt crisis in the EU region. Even though there are certain differences in the nature of the crisis, the possibility of an economic disaster around the world looms over. Bangladesh suffered from the previous financial crisis with a time lag. The country also fears a similar lagged blow from the EU crisis as that region is one of her major trading partners. Export, Aid, FDI and remittance of Bangladesh are feared to suffer from the EU sovereign debt crisis but the impact might not be immediate in case of this crisis as well.
\end{abstract}

Keywords: Bangladesh Economy, EU Debt Crisis, Global Financial Crisis

\section{Introduction}

The early signs of the 2010 European Economic Crisis started emerging during a period of the late 2000s when several members of European Union began to experience the persistent fiscal deficit in their economies. This situation has triggered concerns regarding financial stability of EU members, who have adopted Euro as their legal medium of transaction. Rising government deficits and debts have hinted about the possible collapse of the Euro. Greece, Spain, Italy, Portugal and Ireland are considered to be the five largest risks to the future of the EU economy [1].

The magnitude of impact from the crises probably would depend on the extent of integration with the rest of the world or the extent of liberalization that has taken place. Experience from the recent global financial crises shows Bangladesh has been an outlier with some lag to the consequences in a number of ways. Indeed, impacts were felt in an intense manner during the second half of 2009, when many developed countries (Bangladesh's major import sources and export destinations) were beginning to recover [2]. Thus the current EU debt crises should be a concerning issue for a rapidly liberalizing economy like Bangladesh since EU is one of her major trading partner constituting about 31.19\% of total global trade with Bangladesh.

\section{Literature Review}

In order to explore how the EU debt crises would translate into an economy like Bangladesh, we have looked into a few relevant studies. Our focus is to explain the growth prospect and debt crises nexus of an economy and how it impacts on other economies because of exposed global linkages.

Calvo (1998) explained that countries that join a monetary union lose more than one instrument of economic policy such as their capacity to issue debt in a currency. Thus member countries of a monetary union become vulnerable because of the liquidity flows triggered by changing market sentiments which ultimately connects to solvency crises [3]. Eichengreen et al. (2005) further explained that the liquidity crisis raises the interest rate which in turn leads to a solvency crisis which is not unique for members of a monetary union. There are further important implications of the increased vulnerability of member-countries of a monetary union [4]. De Grauwe (2011) and Wolf (2011) illustrated that countries in a monetary union can be forced into a bad equilibrium, characterized by deflation, high interest rates, high budget deficits and a banking crisis as because members of a monetary union loose much of their capacity to apply counter-cyclical budgetary policies[5].

Danieal et al. (2010) studied fiscal consolidation in 
advanced economies over the past 30 years by using simple statistical techniques to investigate the short-term growth effects of consolidation and how those effects are influenced by such factors as monetary policy, international trade, the form of the consolidation and perceived sovereign risk. Their studies found that, fiscal consolidation typically has a contractionary effect on output. Generally the central banks offset some of these pressures by cutting policy interest rates. However the longer-term rates also typically decline, cushioning the impact on consumption and investment. In addition net exports spur due to nominal depreciation or currency devaluation [6].

Bianca et al. (2006) assessed the size and types of costs associated with sovereign default of the emerging market economies witnessed over the past 30 years. Their findings stated that sovereign defaults have the biggest impact on domestic output when they are combined with widespread failure of the domestic banking system and particularly when there is a triple (sovereign, banking and currency) crisis. And in some cases, such as following the Latin American crisis in the early 1980s and the more recent Russian crisis, sovereign defaults have precipitated broader instability in the global financial system [7]. Dooley (2000) showed that default is often associated with a decline in output growth that is assumed to be due to domestic residents being unable to borrow from domestic as well as foreign creditors in the aftermath of crises [8].

Caprio and Klingebiel (2003) explained that sovereign crises have usually materialized in recessions, when government and/or external debt has been large generally over $60 \%$ of GDP and the fiscal balance in deficit (of over 2\% of GDP). Although annual inflation was rapid in some cases, for example over $50 \%$ in Indonesia and Ecuador, it was negative or low in others, such as Argentina and Uruguay. He further noted that nearly all recent debt crises have been associated with a banking and/or currency crisis [9].

Evidence from literature shows that, a crisis usually effects a externally driven economy through the various transmission channels of exports, imports, remittances, aid, foreign direct investment (FDI) flows, employment i.e. labor market, domestic resource mobilization, gross domestic product (GDP) growth and ultimately poverty. However, the depth of the consequences varies during different phases in crises.

Murshid et al. (2009) illustrated that despite fears of markets drying up, factories closing down and largescale bankruptcies in the wake of the global recession, Bangladesh has coped well, especially in the US market during the Global Financial Crises of 2007. According to him, there is little doubt that the recession has affected labor market prospects in abroad adversely [10]. Mujeri
\& Shahiduzzaman (2008) while assessing the impact of global financial crises stated that the Bangladesh economy is on track in terms of major macroeconomic fundamentals [11].

Adamu (2008) study examined the influence of the Global Financial Crisis on Nigerian economy. It was discovered that the financial crisis will cause fall in commodity prices, decline in export, lower portfolio and FDI inflow, fall in equity market, decline in remittance from abroad etc [12]. Applying general equilibrium framework and relating them to shocks of demand composition, trade frictions, deficits, and productivities across several sectors to the recent recession, Eaton et al. (2008) found that shocks to manufacturing demand, particularly for durables, account for the bulk of the decline in trade/GDP across countries [13]. Karshenas (2009) noted that the impact of the global economic crisis on different LDCs has varied depending on the nature of their trade specialization. He stated that the global economic crisis has led to a sharp reduction in world trade and rapid decline in commodity prices and it is one of the main mechanisms through which LDCs have been affected. Besides, decline in FDI has affected LDCs, particularly the oil and mineral exporting ones and remittance inflow, ODA budget, migration are the other mechanisms affected in the crises [14].

\section{The EU Crises: Current State}

In the early 2010, concerns of a sovereign debt crisis developed in some EU members like Portugal, Ireland, Italy, Greece, Spain etc. This led to a crisis of confidence on debt instruments issued by these countries. The transmission into the global economy was extremely rapid because of the strong integrated financial system and trade. The crisis is most severe in Greece with threats to some other EU countries.

The European economy in the current situation with real GDP projected is expected to face the sharpest contraction in the history of the European Union. According to IMF estimation, the current GDP annual growth projects a slow growth for the next six years (2011 - 2016) after a sharp fall in the growth that EU is experiencing since 2007 (Figure 1). The severely debt crises concerning countries like Ireland, Greece, Spain show negative growth rate in recent times compared to previous years (Table 1).

The seriously indebted countries are relying on European Central Bank (ECB) and International Monetary Fund (IMF) for rescue packages. These countries are looking to tighten fiscal discipline, increase economic policy coordination, and review budgetary rules.

Regardless of the corrective measures that are chosen 


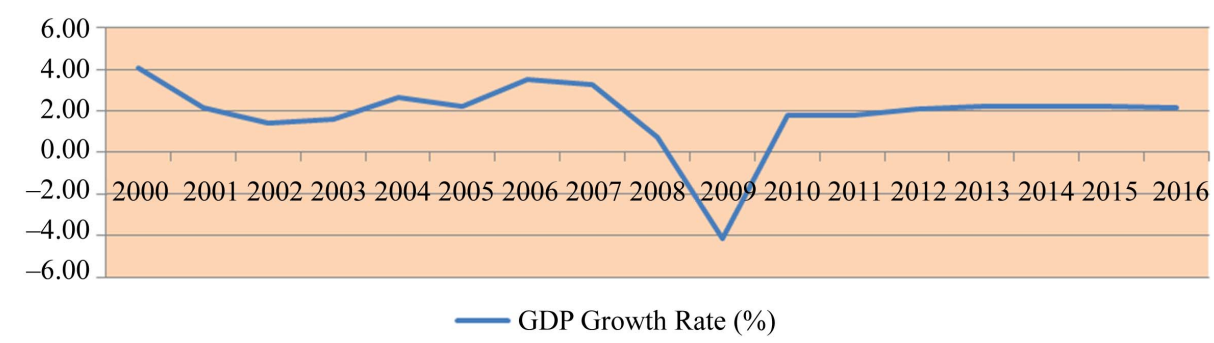

Figure 1. Annual Growth rate EU (\%). Source: World Economic outlook April, 2011 IMF.

Table 1. GDP growth rate and Debt GDP Ratio of EU affected members (all in \%).

\begin{tabular}{|c|c|c|c|c|c|c|c|}
\hline \multirow{2}{*}{ Country } & \multicolumn{3}{|c|}{ Debt GPD Ratio (\%) } & \multirow{2}{*}{$\begin{array}{l}\text { GDP at current price (Billion USD) } \\
2009\end{array}$} & \multicolumn{3}{|c|}{ Annual GPD Growth (\%) } \\
\hline & 2000 & 2005 & 2010 & & 2000 & 2005 & 2010 \\
\hline Greece & 103.44 & 100.29 & 142.02 & 329.92 & 4.48 & 2.28 & -4.54 \\
\hline Ireland & 37.76 & 27.25 & 96.15 & 227.19 & 9.67 & 6.02 & -1.04 \\
\hline Italy & 109.17 & 105.94 & 119.01 & 2112.78 & 3.69 & 0.66 & 1.30 \\
\hline Portugal & 48.48 & 62.75 & 83.32 & 232.87 & 3.93 & 0.76 & 1.40 \\
\hline Spain & 59.26 & 43.03 & 60.11 & 1460.25 & 5.05 & 3.62 & -0.15 \\
\hline Belgium & 107.92 & 92.13 & 97.14 & 471.16 & 3.80 & 2.02 & 1.97 \\
\hline USA & 54.84 & 61.65 & 91.55 & 14119 & 4.14 & 3.05 & 2.83 \\
\hline
\end{tabular}

Source: World Economic Outlook April 2011, IMF and World Development Indicator, World Bank.

to solve the current problem, it is believed that the ongoing crisis is likely to retain and leave long lasting traces on socio economic indicators. Over 23 million EU workers have become unemployed as a consequence of the global economic crisis of 2007 - 2010, whilst thousands of bankers across the EU have become millionaires despite collapse or nationalization (ultimately paid for by taxpayers) of institutions they worked for during the crisis, a fact that has led many to call for additional regulation of the banking sector across not only Europe, but the entire world [15].

\section{Difference between US Financial Crisis and EU Sovereign Debt Crisis}

The financial crisis in the US was not related to the performance of US Government's Bonds. It was a liquidity crisis almost entirely triggered by fears of potential insolvency of US financial institutions due to the fact that a relatively small percentage of mortgage loans were being defaulted on. In fact, in the root of that crisis were rapid credit growths, low risk premiums, abundance of liquiddity, rises of asset prices, strong leveraging and bubble in the real estate. On the contrary, the EU sovereign debt crisis originated in the government's end even though the first sign of crisis might have been noticed in banking sector. For a long time, the government's expenditure had been exceeding the income which resulted in the accumulation of a too high debt burden (Table 1). It must be kept in mind that it could be that the same set of investors was hurt in the previous crisis that made them less resilient to the debt crisis. China's policy of diversification of foreign exchange holding from USD to Euro may have lessened the pitfalls of sovereign debt crisis. USA, also having high Debt-GDP ratio (Table 1), have been avoiding a crisis for many a reasons. One of those reasons, probably the most important one, is that the USA has the control over currency.

If there is a crisis in an economy, the impact on rest of the globe will be higher depending firstly on the more the economy is integrated to the rest of the world (Table 2) and secondly on the size of the originating economy (Table 1). The net role the originating economy plays in global economic scenario (of consumer/ producer/ investor etc.) will also have an influence.

\section{Impact on an Economy of a Persistent Fiscal Deficit}

Central Government's dependency on borrowing may have differences in implication for economies. Lower income economies, higher income economies, economies integrated in an economic union possibly have their own kind of consequences. Such consequences may also differ depending on the extent, reason or borrowing pattern even for economies in similar income ranges. Most influential factor in this regard would be the reason for borrowing or where this borrowed fund would be put. 
Table 2. Degree of openness of EU severely affected countries, USA \& BD (in \%).

\begin{tabular}{ccccccccccc}
\hline Year & Greece & Ireland & Italy & Portugal & Spain & Belgium & EU & US & BD \\
\hline 2000 & 61.81 & 180.16 & 53.19 & 69.17 & 61.13 & 167.61 & 71.10 & 25.72 & 6.73 \\
2001 & 60.14 & 181.2 & 52.8 & 67.02 & 59.48 & 166.41 & 70.74 & 23.49 & 6.76 \\
2002 & 54.98 & 170 & 50.45 & 64.25 & 56.76 & 153.20 & 68.40 & 22.73 & 6.88 \\
2003 & 51.21 & 150.58 & 48.54 & 62.7 & 54.99 & 149.24 & 67.30 & 23.13 & 8.51 \\
2004 & 53.48 & 151.56 & 49.91 & 65.22 & 55.92 & 154.35 & 69.90 & 25.04 & 10.19 \\
2005 & 52.61 & 150.73 & 51.98 & 65.41 & 56.73 & 161.00 & 73.15 & 26.30 & 10.26 \\
2006 & 54.42 & 148.32 & 56.31 & 71.31 & 59.22 & 163.85 & 78.22 & 27.69 & 12.1 \\
2007 & 56.33 & 151.62 & 58.22 & 73.28 & 60.86 & 161.10 & 79.22 & 28.62 & 12.32 \\
2008 & 58.68 & 155.83 & 58.47 & 76.03 & 59.05 & 167.85 & 81.64 & 30.57 & - \\
2009 & 47.19 & 161.61 & 48.5 & 64.52 & 49.35 & 141.15 & 71.83 & 25.04 & - \\
\hline
\end{tabular}

Source: World Development Indicators, World Bank.

Debt used for financing an investment in infrastructure, education, basic health care etc. is expected to have positive influences on economy at least up to a critical level of borrowing. On the other hand, debt financing of unemployment benefit, retirement benefit, previous debt servicing etc. may have a negative consequence even on a lower level of borrowing. Sources of borrowing have their differences in consequence as well. Borrowing from the domestic source, a transfer of resources within the economy, may just crowd out funds for the private sector. While, external debt brings new resources to the economy. If the debt is denominated in a foreign currency, then governments loose the option of monetizing the debt in case of urgency.

In an economic union the individual economies do not have the authority to print currency and repay even if the debt was denominated in their local currency. Greater integration among member countries would help prevent similar crises by insulating the vulnerable economies. Integration would create a more unified economy, where individual economies would be less independent and more reliant upon the union as a whole. However, fierce nationalism within both indebted and more stable countries may remain as an obstacle to integration [16]. Lower income countries often finance their infrastructural developments, basic health care facilities, education etc. through debt financing. On the other hand, higher income countries would often finance their less productive sectors by means of debt. In that way, a lower income country with growth potential and a sensible usage of borrowed fund may have a higher capacity to absorb debt before crossing their critical level of Debt-GDP ratio.

\section{Bangladesh Economy: Implications from EU Debt Crises}

Bangladesh has become increasingly integrated into the global economy over the past couple of decades which has resulted from rationalizing of tariff rates, removal of anti export bias, encouraging incentives for export oriented activities etc. The degree of openness of the economy rose from $14 \%$ to $40.2 \%$ and the extent of globalization $^{1}$ increased from $21 \%$ to $54 \%$ during Fiscal Year 1980/81 and 2009/10 (Table 3). Although increasing global integration has created an opportunity for Bangladesh to take advantage of the global economy, it has also exposed the country to vulnerabilities originating from global shocks. Indeed, the ongoing EU crisis encompasses many of the challenges that a low-income economy such as Bangladesh may face as it strives to become integrated into the global economy. Nature of the impact will depend on the dimensions of the relationship with the effected EU economy.

\subsection{Transition Channels}

The key channels through which the EU crisis is likely to spill over the economy are exports, remittances, imports, foreign aid, foreign capital inflow etc. channels. The major slowdown is anticipated to be in the area of exports as $\mathrm{EU}$ is the largest destination of export for Bangladesh (especially readymade garments). In addition, remittances may ease as the source economies face lower growth and challenging times, aid inflow may reduce, and Bangladesh's macroeconomic stability and growth prospects may suffer.

\subsubsection{Exports}

For Bangladesh, composition of exports makes this the

${ }^{1}$ Degree of openness is defined as share of export and import as a percentage of GDP. Extent of globalization is defined as export + import + official development assistance + remittance + foreign direct investment as a percentage of GDP. This definition may not be a good measure for a developed economy but the same measure has been used for the ease of comparison. 
Table 3. Degree of openness \& Extent of Globalization (million USD).

\begin{tabular}{|c|c|c|c|c|c|}
\hline Indicators of Trade Integration & $\mathrm{FY}^{2} 1981$ & FY1991 & FY 2001 & FY 2008 & FY2010 \\
\hline 1. Export (X) & 725 & 1718 & 6467 & 14088 & 16204.7 \\
\hline 2. Import (M) & 1954 & 3472 & 9335 & 20217 & 23738.4 \\
\hline 3. Remittance (R) & 379 & 764 & 1882 & 7915 & 10987.4 \\
\hline 4. ODA Disbursed & 1146 & 1733 & 1369 & 1873 & 2080 \\
\hline 5. FDI (net) & 0 & 24 & 550 & 650 & 636 \\
\hline Total (1 to 5) & 4204 & 7710.5 & 19603.4 & 44743.8 & 53646.5 \\
\hline GDP (Current Price) & 19811.6 & 30974.8 & 47306 & 78996.9 & 99434.3 \\
\hline Extent of Globalization (\%) & 21.2 & 24.9 & 41.4 & 56.6 & 54 \\
\hline $\begin{array}{c}\text { Degree of Openness } \\
\text { (Export + Import as \% of GDP) }\end{array}$ & 13.5 & 16.8 & 33.4 & 43.4 & 40.2 \\
\hline
\end{tabular}

Source: Authors' calculation (compiled from Bangladesh Bank and EPB).

most vital transmission channel of the effects of recent global financial developments. Two features contribute significantly toward increasing the export sector vulnerability: first, high dominance of RMGs in total export basket; and second, major dependence of Bangladesh's RMG exports on EU markets. The reliance on the EU market is obviously for the quota free entry and the duty free access under GSP. Bangladesh exported about $52.70 \%$ of its total export to EU in FY 2009-10.

Figure 2 presents the total import of EU countries from Bangladesh. Here it is clear that import for most counties here have increased in recent years notably in 2009 and 2010 compared to the same period of 2007.

The impact on the export sector will depend on the severity, duration and recovery of each EU member from the crises and also on the pace of Bangladesh's preparation in facing the stiff competition that it would face with the new GSP facility.

\subsubsection{Imports}

Considering the current economic growth of Bangladesh and its implication on terms of trade, it is important to assess the possible impact of the EU debt crises on import. Bangladesh imported about $10 \%$ of its total import from EU during 2010.

About 50\% of total imports from EU consist of goods such as machinery, nuclear reactors, boilers and electrical equipments. If the prices of these goods fall, then sectors where these are used may enjoy lower prices (Table 4).

\subsubsection{Foreign Aid}

The aid budget in advanced economies is under pressure due to their reduced ability to sustain recent levels of foreign aid resulting from debt overhang and weak fiscal positions created by the financial crisis and slow growth.

\footnotetext{
${ }^{2}$ In Bangladesh Fiscal Year runs from July to June.
}

This would particularly affect the flow of bilateral aid to recipient countries. About $10 \%$ of the total foreign aid in the form of grant is passed on to the economy of Bangladesh from EU countries (Figure 3).

\subsubsection{Foreign Direct Investment (FDI)}

Since most FDIs in Bangladesh are longer term in nature and domestic market based, the current financial crisis is unlikely to have an immediate impact. The full impact would only be clear when investors begin to assess longer term investment decisions depending on global growth prospects and price developments.

The net inflow of FDI has remained relatively stable in recent times. Capital flows in the form of portfolio investment is minimal. The percentage of inflow of foreign investment from EU countries is about 25\% in the year 2010 which was about $50 \%$ at the beginning of the 2000 s. The reason for the decline in inflow can be assessed as the impact of financial crises as it started long before (Figure 4).

\section{Conclusions}

From the above discussion it is evident that, Bangladesh economy is somewhat shield, for the moment, from the current financial turmoil. In particular, the relative isolation of the country's capital market and limited role of foreign portfolio investment supported by reasonably strong macroeconomic fundamentals and strengthened policy and management frameworks have ensured defense from the worst consequence in the global financial crisis, global growth slowdown and other consequences like the EU debt crises. Though a severe crisis is prevailing in the EU zone, significant uncertainty still surrounds the nature, scope, severity, and duration of the crisis and thus it is difficult to derive a quantitative assessment of the impact of the crisis on the Bangladesh 


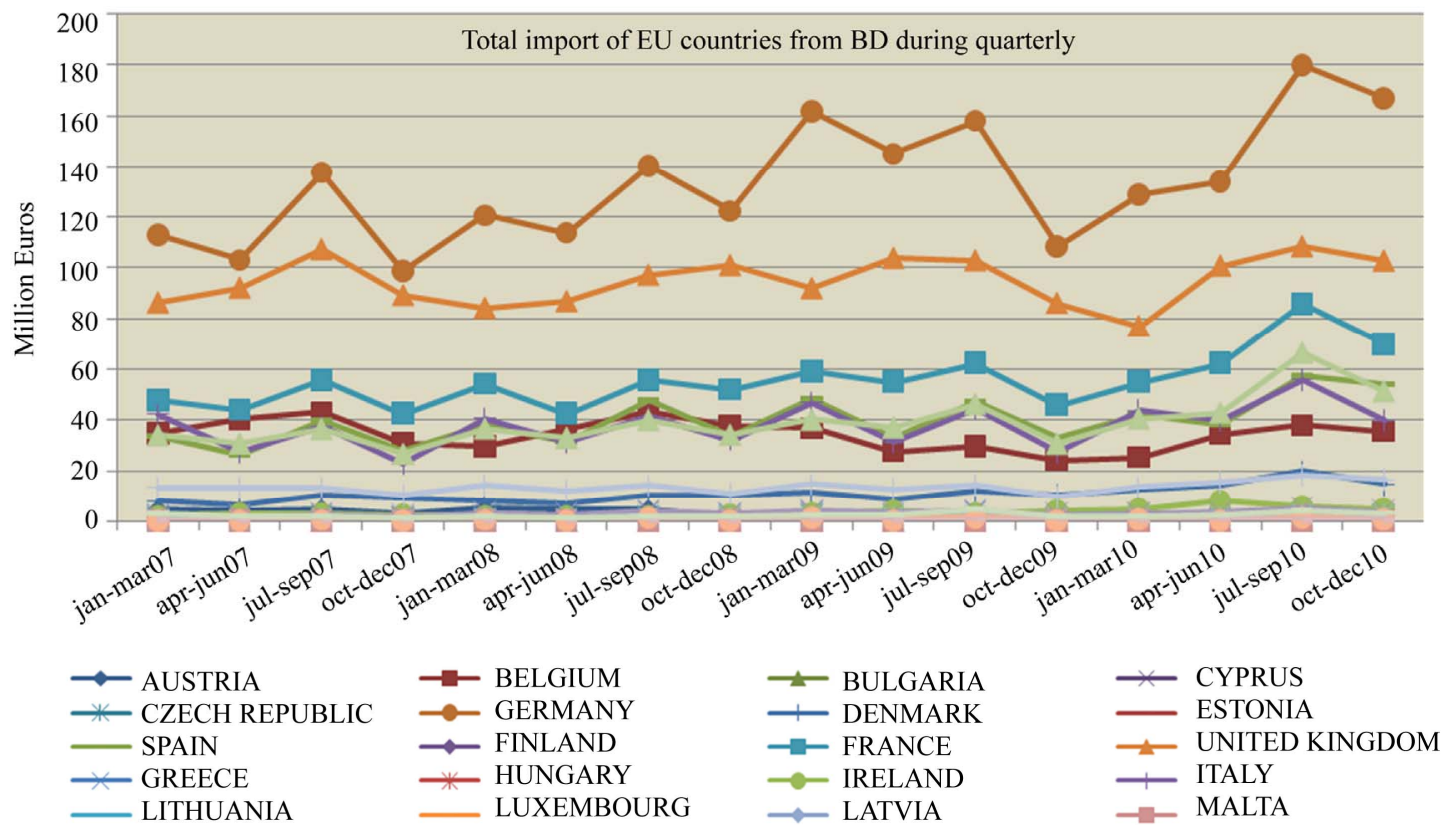

Figure 2. Total quarterly import of EU countries from Bangladesh ${ }^{3}$ (million Euro). Source: Eurostat.

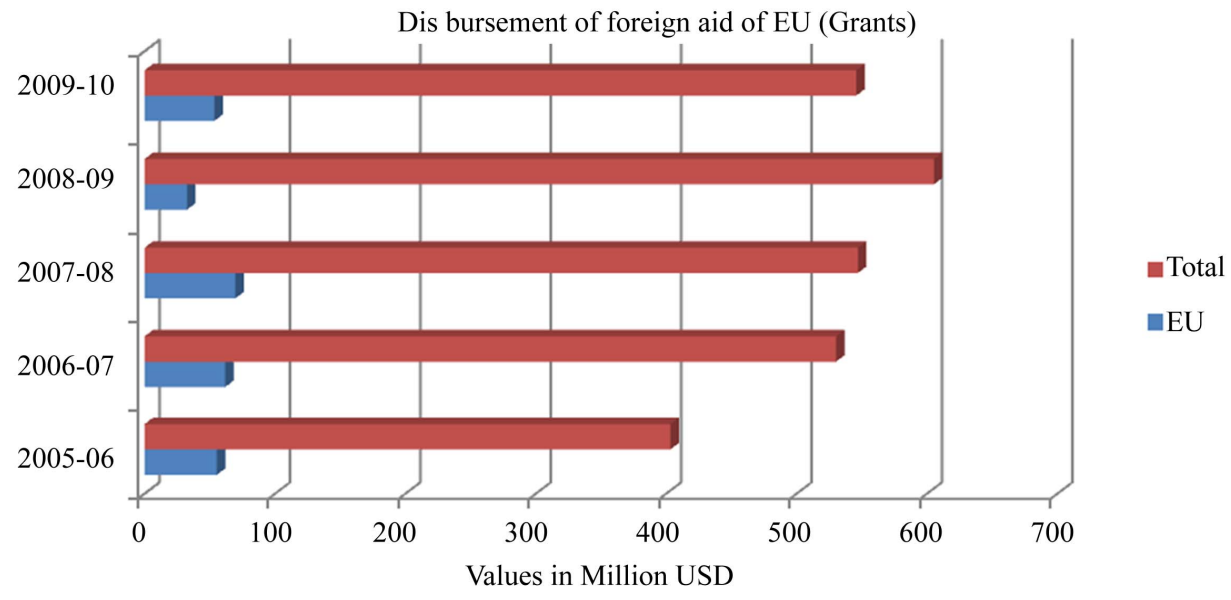

Figure 3. Disbursement of Foreign Aid: EU (million USD). Source: External Resource Division, Government of Bangladesh.

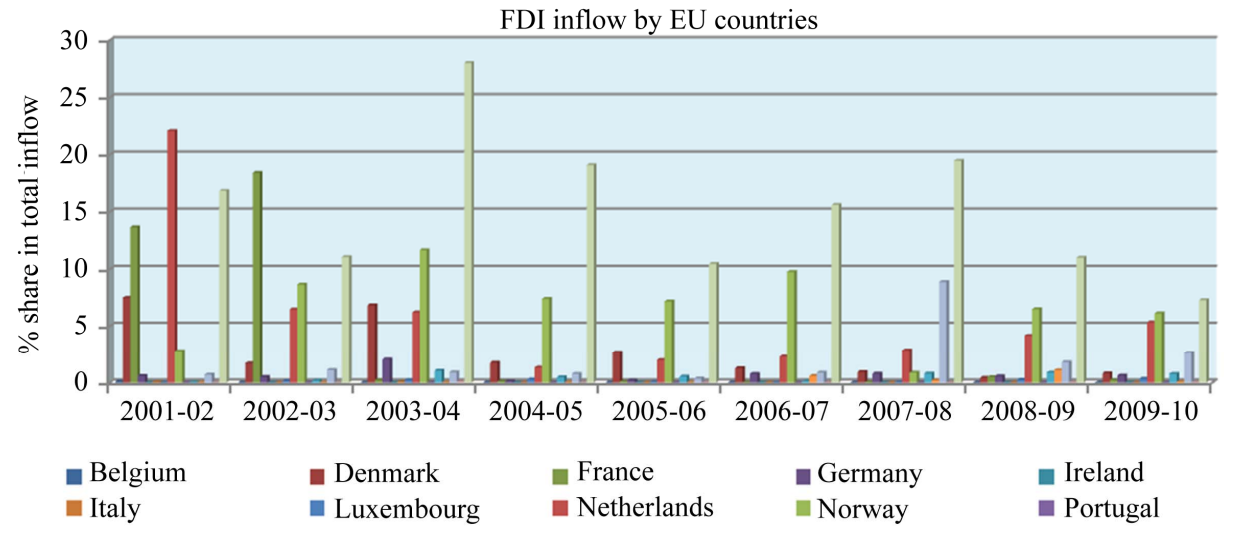

Figure 4. Percentage share of FDI by EU countries in total inflow. Source: Statistics Department, Bangladesh Bank.

${ }^{3}$ We have used import data of EU from Bangladesh instead of exports of Bangladesh to EU since latest data were not available in this manner. 
Table 4. EU top 10 products exported to Bangladesh ('000 USD).

\begin{tabular}{cccc}
\hline HS code & Product Label & Value in 2010 & Share in total export \\
\hline '84 & Machinery, nuclear reactors, boilers, etc & $31 \%$ \\
'85 & Electrical, electronic equipment & 656496 & $19 \%$ \\
'30 & Pharmaceutical products & 389232 & $5 \%$ \\
'10 & Cereals & 112329 & $5 \%$ \\
'72 & Iron and steel & 985167 & $5 \%$ \\
'99 & Commodities not elsewhere specified & 80186 & $4 \%$ \\
'90 & Optical, photo, technical, medical, etc apparatus & 54280 & $3 \%$ \\
'38 & Miscellaneous chemical products & 50369 & $2 \%$ \\
'04 & Dairy products, eggs, honey, edible animal product & 45323 & $2 \%$ \\
'48 & Paper \& paperboard, articles of pulp, paper and board & 41881 & $2 \%$ \\
TOTAL & All products & 2100719 & \\
\hline
\end{tabular}

Source: ITC, Trademap.

economy. But learning from the recent financial crisis provokes the anticipation of negative impacts on the economy, especially through export in the long run.

\section{References}

[1] "Economic Crisis in Europe: Causes, Consequences and Responses,” Economic and Financial Affairs, European Union, 2009.

[2] M. Rahman, A. M. Iqbal, T. Islam and S. Dasgupta, “Global Financial Crises: Bangladesh Phase 2," Discussion Series, Paper 12, January 2010.

[3] Calvo and Guillermo, "Servicing the Public Debt: The Role of Expectations," American Economic Review, Vol. 78, No. 4, 1998, pp. 647-661.

[4] B. Eichengreen, R. Hausmann and U. Panizza, "The Pain of Original Sin”, Other People’S Money: Debt Denomination and Financial Instability in Emerging Market Economies, Chicago University Press, Chicago, 2005.

[5] P. De Grauwe and W. Moesen, "Gains for All: A Proposal for a Common Eurobond," Intereconomics, May/ June, 2009.

[6] D. Leigh, "Will it hurt? Macroeconomic Effects of Fiscal consolidation," International Monetary Fund, October 2010.

[7] D. B. Paoli, G. Hoggarth and V. S. Orta, "Cost of Sovereign Default,” Financial Stability Paper, No. 1, Bank of England, July 2006.
[8] M. Dooley, "Can Output Losses Following International Financial Crises be Avoided?” National Bureau of Economic Research Working Paper, No. 7531, 2000.

[9] G. Caprio and D. Klingebiel, "Episodes of Systemic and Borderline Banking Crises," Research at the World Bank, 2003.

[10] S. A. K. Murshid, C. S. Zohir, M. Ahmed and I. Zabid, "The Global Financial Crisis Implication for Bangladesh,” BIDS-PRP Working Paper Series 1, April 2009.

[11] K. M. Mujeri and M. Shahiduzzaman, "Navigating the Global Financial Storm: Challenges for Bangladesh,” Policy Paper Series, No. 0903, Policy Analysis Unit, Bangladesh Bank, November 2008.

[12] A. Adamu, "The Effects of Global Financial Crisis on Nigerian Economy,” Nasarawa State University, Nigeria, 2008.

[13] J. Eaton, S. Kortum, B. Neiman and J. Rmalis, "Trade and Global Recession,” National Bureau of Economic Research Working Paper Series 16666, Cambridge, January 2011.

[14] M. Karshenas, "The Impact of the Global Financial and Economic Crisis on LDC Economies," Univesity of London, London, 2009.

[15] “European Cities Hit by Anti-Austerity Protests,” BBC News, September 2010. http://www.bbc.co.uk/news/world-europe-11432579.

[16] J. Levine and M. Gerow, "European Economic Crises 2010,” European Union, 2010. 